Meta

Journal des traducteurs

Translators' Journal

\title{
The Ambivalent Case of Repetitions in Literary Translation. Avoiding Repetitions: a "Universal" of Translation?
}

\section{Nitsa Ben-Ari}

Volume 43, numéro 1, mars 1998

La traduction et l'interprétation en Israël

Translation and Interpreting in Israel

URI : https://id.erudit.org/iderudit/002054ar

DOI : https://doi.org/10.7202/002054ar

Aller au sommaire du numéro

Éditeur(s)

Les Presses de l'Université de Montréal

ISSN

0026-0452 (imprimé)

1492-1421 (numérique)

Découvrir la revue

Citer cet article

Ben-Ari, N. (1998). The Ambivalent Case of Repetitions in Literary Translation. Avoiding Repetitions: a "Universal" of Translation? Meta, 43(1), 68-78. https://doi.org/10.7202/002054ar

\section{Résumé de l'article}

Bien que la répétition joue un rôle majeur dans les textes littéraires, éviter les répétitions est l'une des normes les plus fréquentes en traduction. Au point qu'il serait plus approprié de parler d'un des "universaux" de la traduction. Pour éviter les répétitions, on a recours à des techniques diverses, allant de la suppression pure et simple au remplacement par des synonymes. Quand ces solutions s'avèrent impossibles, le traducteur peut se résoudre à "annoncer" (souligner) la répétition. Éviter les répétitions est une stratégie dominante dans la traduction de textes "canonisés", aussi bien que "semi-canonisés", la seule différence résidant dans le nombre de cas relevés et dans l'audace de la solution. Dans les textes semi-canonisés qui ont subi un changement de genre au cours du processus de traduction, éviter les répétitions doit être considéré comme faisant partie d'un complexe normatif plus large. Pour la littérature non canonisée, les "libertés" que se permet le traducteur sont telles qu'il serait peu rentable de rechercher un équivalent adéquat des répétitions. Dans le cadre global des normes, des répétitions sont parfois ajoutées en traduction. Elles sont, cependant, de nature différente, suscitées par des contraintes répertorémiques, normatives. Tant la rigidité que la récurrence de cet "universel" en matière de traduction, dans des langues et des systèmes littéraires si nombreux, donnent à penser qu'on peut conclure que des considérations d'adéquation cèdent le pas à des considérations d'acceptabilité dans la culture-cible.
Ce document est protégé par la loi sur le droit d'auteur. L'utilisation des services d’Érudit (y compris la reproduction) est assujettie à sa politique d'utilisation que vous pouvez consulter en ligne.

https://apropos.erudit.org/fr/usagers/politique-dutilisation/ 


\title{
THE AMBIVALENT CASE OF REPETITIONS IN LITERARY TRANSLATION. AVOIDING REPETITIONS: A "UNIVERSAL" OF TRANSLATION?
}

\author{
NITSA BEN-ARI \\ Tel Aviv University, Tel Aviv, Israel
}

\section{Résumé}

Bien que la répétition joue un rôle majeur dans les textes littéraires, éviter les répétitions est l'une des normes les plus fréquentes en traduction. Au point qu'il serait plus approprié de parler d'un des «universaux» de la traduction.

Pour éviter les répétitions, on a recours à des techniques diverses, allant de la suppression pure et simple au remplacement par des synonymes. Quand ces solutions s'avèrent impossibles, le traducteur peut se résoudre à «annoncer» (souligner) la répétition.

Éviter les répétitions est une stratégie dominante dans la traduction de textes «canonisés», aussi bien que "semi-canonisés», la seule différence résidant dans le nombre de cas relevés et dans l'audace de la solution. Dans les textes semi-canonisés qui ont subi un changement de genre au cours du processus de traduction, éviter les répétitions doit être considéré comme faisant partie d'un complexe normatif plus large. Pour la littérature non canonisée, les «libertés» que se permet le traducteur sont telles qu'il serait peu rentable de rechercher un équivalent adéquat des répétitions.

Dans le cadre global des normes, des répétitions sont parfois ajoutées en traduction. Elles sont, cependant, de nature différente, suscitées par des contraintes répertorémiques, normatives.

Tant la rigidité que la récurrence de cet «universel» en matière de traduction, dans des langues et des systèmes littéraires si nombreux, donnent à penser qu'on peut conclure que des considérations d'adéquation cèdent le pas à des considérations d'acceptabilité dans la culturecible.

\footnotetext{
Abstract

Although repetitions have a major function in literary texts, avoiding repetitions is one of the most recurrent norms of translation. So much so that it may be more accurate to refer to it as a "universal" of translation.

The techniques of avoiding repetition vary from cancelling them altogether to replacing them with synonyms. When such solutions are impossible, translators may revert to "announcing" the repetition.

Avoiding repetitions is predominant in canonised and semi-canonised texts as well, the only variation being the number of cases and the crudity of the solution. In semi-canonised texts which have, in the process of translation, undergone a change of genre, avoiding repetition must be regarded as part of a larger normative complex. In non-canonised literature, the "liberties" taken by translators are such that it would be unprofitable to look for an adequate rendering of repetitions.

Within the overall framework of norms, repetitions are sometimes added to translated texts. They are of a different nature, however, stemming as it were from repertoremic, normative constraints.

Both the rigidity and the recurrence of this "universal" of translation in so many languages and so many literary systems may point to the conclusion that considerations of adequacy come second to considerations of acceptability in the target culture.
}

Meta, XLIII, 1, 1998 


\section{INTRODUCTION}

Avoiding repetition of words or phrases is part of a set of translation norms found to operate consciously or subconsciously on the translator (Toury 1977, 1996; Ben-Ari 1988) and dictating the nature, and adequacy, of the translated text. Being one of the most recurrent norms, it can, in fact, supply research with an insight into the intricate relationship between textual and inter-textual relations, between considerations of adequacy and acceptability. In fact, it is so common and widespread, transcending differences between languages and cultures, that the term "norm", being local in nature, fails to apply to it, and one might call it a "universal of translation".

This essay will attempt to analyse the relationship between the functional role of repetition in the literary text and the stylistic norms opposing repetitions. It will describe the various means used in translation for avoiding repetitions and discuss the deviations from adequacy, textual or generic, ensuing from these procedures. It will also point out the seemingly contrasting phenomenon of the addition of repetitions to translations, and will attempt to describe the nature and function of the latter.

For this purpose my research makes a distinction between canonised and semi/non-canonised texts, in an attempt to show whether the position of the text or the author in the source literature is indeed a major factor in the process of translation and in the adherence to norms. This essay will not deal with non-canonised literature, in which the "liberties" taken by translators prevent any systematic discussion of the treatment of repetitions.

The testcases presented here have been chosen from a wide variety of texts which I have examined, with special emphasis on translations into French, since among European languages French is of the most normative type. Moreover, French normative respect for "elegance of style" has resulted in sets of written "recommendations" for what is "proper" or "improper" in writing. Repetitions, in these handbooks, usually appear at the head of lists of prohibitions.

For reasons of transcription, it is not possible here to discuss the treatment of repetitions in Hebrew literature. It is important to note, however, that Hebrew translations tend to behave just as rigidly in respect of avoiding repetitions, while favouring and inserting repertoremic repetitions. The Hebrew Enlightenment (Haskala), reviving the language in the late 18th Century on the basis of Biblical Hebrew, was greatly in favour of collocations such as binoms and binoms of synonyms, remnants of which can be found in normative Hebrew stylistic till today.

This essay must artificially isolate the treatment of repetition, although it figures as part of a complex set of norms that serve, on the whole, to "embellish" the text, and to "amplify", "correct" and "clarify" it (see Ben-Ari 1988 for a more complete analysis of the procedure).

\section{THE ROLE OF REPETITIONS IN LITERARY TEXTS: TEXTUAL RELATIONS VS. TRANSLATION NORMS}

Repetitions have vast and various literary functions, depending on genre, period and writer, which cannot be enlarged upon in this context. They may have a generic function - as they do in comedy, for instance, where repetitions (lingual or situational) function as part of the comic inventory of devices. They play an important role in myths, legends and folk tales, where they provide the generic frame of reference. They have a wide range of functions in poetry, where they may serve as musical, thematic or symbolic devices. They have traditionally served as "hypnotic" religious elements in sacred texts. They may function as a simulator of dialogues or spoken language in modern literature. At times they are significant to a point where they may provide the key to the reading, understanding or even decoding of the literary text. 


\subsection{Repetitions in Normative Stylistic}

Modern translation studies, however, have demonstrated that procedures adopted by translators, and the norms behind those procedures, do not necessarily correspond to textual relations (Even-Zohar 1974; Toury 1977). Notwithstanding the importance of repetitions, therefore, it is not surprising to find that one of the most persistent and inflexible norms in translation, in all languages studied (by myself and by collegues elsewhere), is that of avoiding repetitions. Since the behaviour of norms is neither logical nor conscious, it seems that avoiding repetitions has to do with a deep-rooted need to display richness of vocabulary, passed down by generations of normative stylistic do's and don'ts and extremely difficult to root out. In western civilizations richness of vocabulary is, supposedly, a mark of class and culture, of intelligence and rank, whereas meagerness of vocabulary has traditionally been associated with poverty of means, intellectual or otherwise. Generations of teachers and educators have attempted to produce the "cultured" person of good manners and a general "Bildung" or "Kultur", who is to be recognised by his vocabulary. It seems that, from kindergarten on, pupils have been complimented on their rich vocabulary and reprimanded for repetitiveness.

The French culture, extremely normative since its classical Glorious Age, has a special, well-known aversion for repetition, not only of the same words but also of words of the same origin or root. It is therefore productive to study attitudes towards repetitions in French textbooks and in translations into French. A classical textbook of French stylistics warns the student that repetitions are "shocking to the ear", that repetitions of words of the same root are "equally shocking" and that "repetitions are to be avoided by the use of synonyms." H. Bonnard, a well-known professor of stylistics, voices these normative recommendations, though he is of course only one example amongst many. His illustrious example for the use of synonyms is La Fontaine, while inelegant repetitions are quoted from pupils' notebooks. The following passage is taken from his Notions de style, de versification et d'histoire de la langue française (1953: 26-27):

La répétition d'un mot à bref intervalle — sauf s'il s'agit d'un mot accessoire comme le, un, de, à, par... ou d'un mot d'emploi très banal comme être, avoir — frappe toujours l'oreille. [...] La répétition est désagréable quand elle n'a pour cause que l'indigence du vocabulaire.[...] Le rapprochement de deux mots de même radical choque aussi: "son fils se dirige dans une direction opposée" (copie d'élève). On évite les répétitions par l'emploi de synonymes. [...] La Fontaine, pour ne pas répéter le mot âne dans la fable $\mathrm{X}$ du second livre, recourt aux expressions suivantes: deux coursiers à longues oreilles, nos gaillards pèlerins, l'autre bête [...] Remarque: Bien entendu la répétition est tolérée dans un exposé scientifique, une rédaction administrative où le besoin de précision l'impose.

Modern literature has made the use of repetitions a versatile tool for its various manifestations. But, though acknowledged and frequently used in original literary texts, old-fashioned norms still have the upper hand in translated ones. There is no doubt that translators can identify repetitions and analyse their respective roles in the text. Their first and strongest tendency, however, will be to refrain from using them.

\section{METHODS OF AVOIDING REPETITION}

Roughly speaking, repetitions are handled in two main ways; they are either omitted, or replaced by synonyms. Replacing repetitions can be done in several ways, starting with a variation of the item replaced and ending with a synonymous expression, but once replaced, the result is invariably the same: normative pressures turn every texteme into a repertoreme. The persistence and weight of the norm is reflected in the fact that no text escapes it: the phenomenon is just as widespread in classical literary texts, where respect for the position of the writer 
in the SL could theoretically involve a greater commitment on the part of translators to transfer textual relations by textual means; moreover, it is to be found even in bilingual texts, where, presumably, the proximity of the original should enhance adequacy.

\subsection{Avoiding Repetition in Canonised Texts}

The following excerpts will illustrate the treatment of repetition in canonized German literature. The first examples will be taken from translations of Thomas Mann, Robert Musil and Rainer Maria Rilke, whose position in the source culture is well acclaimed.

Thomas Mann's Buddenbrooks makes frequent use of repetitions in dialogues. A literary analysis will point out that the repetition may serve to endow the dialogues with credibility but also to distinguish between characters/speakers and to simulate emotions.

The following is a dialogue between Tony and Morten, two young people on the verge of discovering first love. Morten, the speaker, is both young, shy and "lower class", elements reflected in his speech. The French translation chose a "higher" register for him, and "elegantly" avoided two repetitions: the repetition of "kaltes" (froid, cold) and the repetition of "Sie" (vous, you). In both cases a lexical solution was available, though stylistically it was inaccessible. Note that the Italian translator could not accept the repetition either:

(1) "Manchmal denke ich: Haben Sie vielleicht ein kaltes Herz? [....] Haben Sie wirklich ein kaltes Herz?" (Mann 1985: 120)
"Je pense quelquefois: aurait-elle un cœur insensible? [....] Avez-vous vraiment un cœur de glace?" (Mann 1965: 133)

"Qualche volta penso: che abbia il cuore gelido? [....] Ha davvero il cuore freddo?" (Mann 1982: 114)

Tony, though from a rich "bourgeois" family, is equally clumsy in her reaction to Morten's confession. Again, the translation disregarded the textual function of the repetition:

(2) "Nein Morten, glauben Sie das von "Non, Morten, est-ce votre opinion?... Il ne mir?...Das müssen Sie nicht von mir faut pas penser cela de moi."

glauben."

"No, Morten. Come può credere una cosa simile?... Non deve pensare così di me."

Not only single words but the whole syntactic pattern was replaced, in order to avoid repetition.

There are cases in which the textemic role of the repetition is to introduce irony or mockery. Such is the case in the repetition of the words said by Tony's second husband, Permaneder, in his Bavarian dialect:

(3) "I mag mei G'muatlichkeit!" [and 7 lines later the narrator quotes him sarcastically:] Ihr leidenschaftlichster Widerstand war an seinem Drang nach "G'muatlichkeit" gescheitert. (Mann 1985: 310)

"J'aime mes aises." [...] Contre son besoin d'insouciant bien-être, la résistance passionnée de Tony s'était brisée. (Mann 1965: 321)

The narrator mocks both his heavy accent and his easy-going Bavarian temperament, as seen through Tony's cold eyes. The translation converted this subtle mockery into an explanatory phrase.

Robert Musil's Drei Frauen is a collection of three novellas or long stories, that can serve as an excellent case-study for the various normative solutions for repetitions, due to the genre's economical use of words. A repetition, in Musil's concentrated, tight prose, stands out 
as a magnified literary tool. The translations either cancel the repetition altogether, replace it partially or — in cases where these procedures seem impossible — announce it.

\subsubsection{Cancelling repetitions}

There are cases where the norm dictates that the repetition be cancelled altogether. Such is the case in Musil's Tonka. Here the original repetition serves as a vehicle for the authenticity of the dialogue:

(4) "Aber ich kann's nicht sagen."

"Das ist etwas, das mir noch nie wiederfahren ist: etwas nicht sagen können!" (Musil 1985: 51)

\subsubsection{Partial replacement of repetitions}

Some repetitions are only partially replaced. The phrase in the following translation is repeated, though using a different verb:
"But I can't say it."

"That's something that never happened to me." (Musil 1966: 76)

- Mais je n'arrive pas à le dire.

-Voilà qui ne m'est jamais arrivé, de ne pas pouvoir dire quelque chose. (Musil 1962: 77)

Since the translator did not use "je ne peux pas le dire" in the first sentence, he cancels the original repetition. The repetition of arriver, on the other hand, though only lexical, is more acceptable to him.

\subsubsection{Announcing the repetition}

There are cases in which the translator is painfully unable to eliminate the repetition altogether, and has to resort to an indirect apology, as if to say that "the fault" lies with the original. This is the case of the following examples. In Musil's Grigia:

(5) "Bist Du noch eine Jungfrau, sag?!" [...]:

"Du bist noch eine Jungfrau?!" Wunderte er sich schnell und lachte. [...] "Sag!?" (Musil 1985: 11)
"Well, and are you still a virgin?" and then: Homo was taken aback: "You're still a virgin!" he repeated, and laughed." [...] "Tell me!" he said." (Musil 1966: 22)

Here apparently, since the repetition of the question could not be cancelled or altered, the translator felt the need to state that a repetition exists. This is done, frequently enough, by adding the formula: "He repeated". On the other hand, yet another repetition, that of "tell me", was unacceptable. The same happens in the French version:

"Alors, tu as encore ton pucelage?" [...] Homo faillit en perdre contenance. "Vraiment, tu l'as encore?" [...] "Réponds!" répéta-t-il. (Musil 1962:18)

Note that the repetition of the word "pucelage" itself has successfully been avoided here, by means of the relative pronoun "le"; so has the repetition of "sag", converted into "réponds" and used only once. The same technique of announcing the repetition appears in Tonka:

(6) "Ja - nein - ja - nein" - er wurde ungeduldig - "was soll das heissen?" (Musil 1985: 15)
- Oui, non, oui, non, répéta-t-il impatienté, qu'est-ce à dire? (Musil 1962: 76) 
It seems that the repertoreme "repeat + number of times" is more familiar in the French repertoire than just a vague "repeated". In the next example from Thomas Mann's Buddenbrooks the repetition occurs because the little girl does not remember her catechism by heart and is "stuck" with the same phrase. The translation specifies exactly how many repetitions occurred:

(7) Und die kleine Antonie [...] wiederholte Alors, la jeune Antonie [...] répéta pour la noch einmal: (Mann 1985: 5) troisième fois: (Mann 1985: 9)

This is not simply a case of concretization of information, quite frequent in itself: it is a well known, highly institutionalized part of literary repertoire; "real-world information" does not matter here so much as repertoire convention. And just as one repertoire would favour the repetition of "he said", so would another see fit to transform it to "he exclaimed", "he cried", "he retorted", etc. Cases like example number 7 are part of a rigid dialogue pattern to be found in many 19th century French original texts. Here is one example from Maupassant's story "Le Papa de Simon", where such a dialogue pattern is recurrent.

- Comment t'appelles-tu, toi?

Il répondit: "Simon."

- Simon quoi? reprit l'autre.

L'enfant répéta tout confus: "Simon."

Le gars lui cria: "On s'appelle Simon quelque chose [...]

Et lui, [...], répondit pour la troisième fois:

- Je m'appelle Simon.

(Maupassant 1973: 177)

\subsubsection{Variations}

There are cases where the repetition is acknowledged, though with variations. Here, too, the norm prevails: the translator will attempt to cancel repetitions that are successive, regardless of the contextual relations. When cancelling is impossible, i.e., when the textemic value of the word or phrase is so obvious that the translator feels he has to render it, he will revert to a variation (a different part of speech, a different tense, etc). The protagonist In Musil's "Tonka" has a very high opinion of himself as a thinking man; the repetition of the words "I think" in the following passage functions not only as a tool for realism in dialogue, but as an ironical echo to his self-esteem. His repetition of "your point of view" "my point of view" may serve as an indication of his so-called liberalism, totally dispelled later on, and his indecisiveness:

(8) "[...] ich denke nicht schlecht von meiner Grossmutter, das ist es nicht; sie ist auch eine arme Frau, aber ich denke jetzt nicht von dieser Seite: das ist meiner Art. Ich denke von Ihrer Seite, und da ist sie ein Klumpen Scheusslichkeit." (Musil 1985: 51)
"[...] ce n'est pas que je pense aucun mal de ma grand-mère, non: elle est à plaindre elle aussi, mais pour le moment permettez-moi de ne pas adopter ce point de vue, mais le vôtre: pour vous, elle n'est qu'un sac d'immondices."

It's not that $I$ think badly of my grandmother, poor woman. No, it isn't that. I'm not looking at it from that point of view at the moment. I can't help thinking of it from your point of view, and from your point of view she's a perfect old horror." (Musil 1966: 75) 
"Think", in the English version, is replaced by two alternatives, a synonym "look at it" and the variation "can't help thinking of it". "Point of view", on the other hand, is repeated three times (while only twice in the original "von Ihrer Seite"), thus missing the subtle irony directed at the speaker. Again a case of a texteme converted into a repertoreme, resulting in total standardization of the text. The Italian version seems to be the most consistent in its anti-repetition policy: "penso" is systematically replaced by three variations:

\begin{abstract}
"Io non penso malo della nonna, non si trata di questo; lo so che è una povera malata, ma io sto considerando la cosa da un altro lato, com'è mia abitudine. Mi metto nei suoi panni." (Musil 1973: 67)
\end{abstract}

\title{
2.1.5. Textual constraints
}

There are very few cases where repetition cancelling is done because of textual, non-normative constraints. Such is the case of M. Betz's translation of Rilke's Die Weise von Liebe und Tod des Cornets Christoph Rilke: the word "reiten", a key word in the original, is frequently picked up and repeated throughout the text. Betz, who chose the older word "chevaucher" for the opening lines, reverts to the more common "monter à cheval" and its variations in the rest of the text, probably for fear of harming the rhythm and the harmony with unusual declinations of this obsolete verb (for discussion of the textemic status of "chevaucher" also see Even-Zohar 1974):

(9) Reiten, reiten, reiten, durch den Tag, durch die Nacht, reiten, reiten, reiten. [...] Die Kleider der Frauen leuchteten lang aus dem Grün. Und nun reiten wir lang. (Rilke 1980: 43)

(10) Sie reiten über einen erschlagenen Bauer. (Rilke, Rainer Maria 1980. Die Weise von Liebe und Tod des Cornets Christoph Rilke. (Rilke 1980: 55)
Chevaucher, chevaucher, chevaucher, le jour, la nuit, le jour. Chevaucher, chevaucher, chevaucher. [...] les robes de femmes ont longtemps brillé dans la verdure. Et voilà longtemps que nous sommes à cheval. (Rilke 1957: 4)

Leurs chevaux passent sur un paysan massacré. (Rilke 1957: 21)

But even in this outstanding attempt at adequacy, there are norm-dictated lapses. The translation could not abide the repetition of the word "drapeau" (flag) three times in three consecutive sentences:

(11) Auf seinen Armen trägt er die Fahne wie eine weisse, bewusstlose Frau. [...] und da kommt auch die Fahne wieder zu sich [...]. Da brennt ihre Fahne mitten im Feind (Rilke 1980: 67)
Sur ses bras il porte le drapeau comme une femme blanche, évanouie. [...] Et voici que l'étendard aussi revient à lui [...]. Voici le drapeau qui brûle au milieu de l'ennemi (Rilke 1957: 37)

\subsection{Treating Repetitions within the Context of Larger Normative Transformations}

It is significant to note how frequently repetitions are cancelled and otherwise avoided within the framework of other normative decisions. This occurs mainly in texts that have not acquired a "classical" or canonized status, either in their own SL or in the TL. It brings forth a discussion of a different angle of the issue at hand, namely, the role that the position of the text in the SL and especially in the TL plays in the preliminary and operational considerations behind translation. 
Unlike Mann, Rilke and Musil, Stefan Zweig, and more so Alfred Döblin, do not occupy central positions in their own SL, even less so in the TLs. It seems therefore profitable to examine how, in this stratum of semi-canonised literature system/repertoire/model constraints are much more automatically adhered to.

In these two cases, however, an overall policy of generic transformation has taken place, due to considerations of acceptability. Both texts have, for different reasons, changed their generic nature in the process of translation. Zweig has been turned from a "psychological novel" into a "romantic novel", for which purpose all parts that do not directly advance the plot have been omitted. Döblin's has been turned from a modern novel, using techniques such as "stream of consciousness", "collage" or "interior monologue", into a realistic novel depicting the underworld of crime. The overall policy, belonging to preliminary decisions prior to the actual translation itself, is in this case responsible for the operational decision of abolishing repetitions.

\subsubsection{The treatment of repetitions in Stefan Zweig's Ungeduld des Herzens}

Repetitions are an integral part of Zweig's style, especially emphatic, "emotional" repetitions. In the following example there are two consecutive repetitions of this kind. They do not appear in the French version, where the whole passage, two pages in length, has been omitted. Both repetitions are rejected in the English version for fear of the unacceptability of precisely that emotional tone. On the other hand, as a result of other normative constraints, the English version introduces a different repetition, an addition of an explanatory nature:

(12) Nichts erhöht ja in einem jungen Menschen dermassen das selbstbewusstsein, nichts fördert derart die Formung seines Characters, als [...]. Selbstverständlich war mir schon früher Verantwortung zugefallen, aber immer war es eine dienstliche [...] gewesen, immer bloss eine Leistung [...]; etwa eine Schwadron zu commandieren (Zweig 1981: 111)
There is nothing that so raises a young man's self-esteem, that so contributes to the formation of his character, as [...]. Responsibility had often come my way before, of course, but it had always been connected with the carrying out of my military duties, with tasks that [...]; duties such as commanding a troop (Zweig 1982: 77)

The addition of the twice repeated "that so" standardizes the text, at the same time ignoring the textemic role of "nichts" and "immer", so natural and pathetic in the mouth of an enthusiastic youth; the repetitive use of "duties" stems from normative, not textual, considerations.

\subsubsection{Repetitions in Alfred Döblin's Berlin Alexanderplatz}

The translations of Berlin Alexanderplatz are full of examples in which significant repetitions in the original no longer retain their role when the translated novel has undergone a generic "metamorphosis". Any "cliché" can, in these cases, replace the textemic repetition:

In the first example Franz Biberkopf is released from prison, and the first moments in the outside world are painfully confusing: he is unable to make a move. The verbs "go" and "not go" are repeated several times, both to illustrate this and also to remain true to the character and vocabulary of a simple, crude, ex-convict:

(13) "Gestern hatte er noch [...] Kartoffeln geharkt mit den andern, [...], jetzt ging er im gelben Sommermantel [...] Er [...] drückte den Rücken an die rote Mauer und ging nicht. Der Aufseher [...] zeigte ihm seine Bahn, er ging nicht." (Döblin 1965: 8)
"Hier encore [...] il avait, avec les autres, buté des pommes de terre [...]; maintenant il portait un pardessus d'été beige.[...] il resta adossé contre le mur rouge. [...] Le gardien lui avait indiqué le tramway à prendre; il ne bougeait pas." (Döblin 1970: 19) 
The next example illustrates Döblin's technique of using repetitive phrases as a kind of echo, sing-song or refrain. These evidently have a textemic value of both thematic and rhythmic character. They may even function as a cynical echo to the Greek chorus. Franz is in immediate danger, to which he is totally — and characteristically — blind:

(14) Was macht denn aber Franz? Der? Na, But what is Franz doing? Him? Well, what was wird er machen? Geht in der Welt do you think he is doing? He goes about, the herum, ist Ihnen die vollste Ruhe und picture of the most complete tranquility and Friedfertigkeit. (Döblin 1980: 290) peacefulness. (Döblin 1982: 340)

The sentence is picked up a few pages later, in the most evocative sing-song:

Geht in der Welt rum, immer in der Welt rum, immer in der Welt rum, ist Ihnen die vollste Ruhe und Friedfertigkeit. (Döblin 1980: 296)

No sign of the repetition in the American version either:

But what is Franz doing? He? Well, what do you think he's doing? He goes flopping around, the picture of the most complete tranquility and peacefulness. (Döblin c1931: 446)

He goes around and around everywhere, the very picture of tranquility and peacefulness. (Döblin c1931: 455)

The French version finds synonymous expressions to replace every item in the repetition:

Mais qu'est-ce qu'il fait, le Franz, celui-là? Et, qu'est-ce qu'il fera? Il se promène, avec calme, paisible comme pas un. (Döblin 1970: 472)

Ce garçon ne fait que circuler, qu'aller de Pierre à Paul, à droite et à gauche, dans un état de tranquillité parfaite et d'humeur pacifique. (Döblin 1970: 480)

The repertoreme "de Pierre à Paul" is added to make the phrase more "French". Stylistic norms also demanded a more perfect balance, a parallel, for which the French translation made several additions ("tranquillité parfaite et humeur pacifique"). Yet, the most significant device of the original, the repetition, has not been recaptured. Both norms, that of rounding up a parallel and of eliminating the repetition operate in the next example as well, in which a long sentence has been cut in two:

(15) Sie kriegt erst einen Schreck, das er da ist und villeicht die Weste gesehen hat, aber der kuckt kaum zu ihr rüber, kuckt immer bloss auf den Tisch und seine Uhr. (Döblin 1965: 100)

The repetition of the verb "regarder" is cancelled, while, on the other hand, a new parallel is created in "fit peur à Lina" and "elle craignait", a result of the French norm of segmenting long sentences. Franz staring at his table was omitted altogether. 
The systematic transfer of textemes into repertoremes, and even more so the complete disregard of recurring sentences, is an indication that there is no question here of violating the interest of acceptability in the TL: the less canonised the work, the more unbending the norms. The Translator's Note in Berlin Alexanderplatz warns the reader of certain "liberties" taken by the translator.

Le traducteur croit de son devoir d'avertir le lecteur français qu'il a usé de quelque liberté dans l'adaptation de certains détails de l'œuvre allemande [...] (Döblin 1970: 15)

Such an admission would hardly appear in works of an even lesser degree of canonicity. In more "classical" literature, on the other hand, the Translator's Note will use a totally different tone of voice. There, the genre demands the "apologetic" approach, a certain "humility" towards the "impossible task". I quote a short passage from the note in the English version of Buddenbrooks:

The translation of a book which is a triumph of style in its own language, is always a piece of effrontery. [...] So the present translation is offered with humility. It was necessary to recognize that the difficulties were great. Yet it was necessary to set oneself to the bold task of transferring the spirit first and the letter so far as might be; and above all, to make certain that the work of art [...] should, in English, at least not come like a translation — which is, 'God bless us, a thing of naught.'

\section{ADDING REPETITIONS}

From the various cases shown above it is evident that there is a tendency not to transfer original repetitions - not out of carelessness nor out of linguistic constraints, but out of normative stylistic considerations, on the assumption that repetitions are not "elegant" and reflect a poor vocabulary; on the other hand, a seemingly contradictory phenomenon occurs, in which new repetitions are introduced by the translators. These would have been regarded as an attempt to compensate for repetitions that could not be accounted for, due to linguistic reasons, were it not for the fact that there is usually nothing to prevent the translator from repeating the same words or phrases. New repetitions are added as a result of other normative considerations, like the wish to embellish or amplify the text. The English translation of the following passage omitted the word "nein" (no), added the word "but", to make the sentence more coherent, and added a repetition of "cool". The whole sentence is now less cryptic, less enigmatic, less shocking — in short, more "acceptable".

(16) Morgen in das kühle Grab, nein, wir And at dawn the cool, cool, grave, but we'll werden uns $\mathrm{zu}$ beherrschen wissen. (Döblin manage to control our feelings. (Döblin 1982: 1965: 99)

$$
\text { 116) }
$$

The "new" repetitions, however, are non-textemic in that they stem from TL considerations, such as repertoire, genre or model constraints.

The few cases analysed above have demonstrated how, like any operational norm, avoiding repetition is closely interwoven with other dominant norms, and its individual operational impact depends on a variety of factors, starting with priorities in the TL and ending with the contextual pressures of other norms.

Within the context of other norms, one can figure out that when the repetition-cancelling norm is subconsciously or consciously weighed against the double opposition of norms of rectification + embellishment, the chances would be against elimination, in fact even for amplification. In those cases repetitions, of words and/or phrases, will be added to the text, to make it "rounder", more coherent, and thus more acceptable. But when weighed against the equally strong norms of rectification + omission (in the case of longer texts or change of genre/model), the opposite will occur. 


\section{IN GUISE OF A CONCLUSION}

Avoiding repetition is such a predominant norm that it seems to be found in all translated texts, no matter how "classical" or canonical. The only variant, extravagances of the individual translator notwithstanding, is sometimes that of quantity, which reflects the degree of willingness, on the part of translators, to sacrifice acceptability for the sake of adequacy. When such willingness does not exist, when translation is at its customary "normal" position as a secondary system within the literary polysystem, rigid normative literary models and "classical" stylistic norms will prevail.

It may be valuable to note that my experience in guiding translation workshops as well as extensive research in my career as editor in a major publishing firm has added more light to the overall picture. The procedure of avoiding repetitions is persistent in assigned translations provided by students, in translations done by both experienced and inexperienced translators and, which is even more significant, in editors' proofs, where you find "corrections" of attempts at "adequate" rendering of repetitions. For the purpose of research, students of translation on the one hand and editors of translated literature on the other may represent the two extremes of characteristic types of normative approach. This, however, should serve as potential material for further research.

\section{REFERENCES}

BEN-ARI, Nitsa (1988): Norms Underlying Translation of German Literature into English, French and Italian, M.A. thesis, Tel Aviv University.

BEN-ARI, Nitsa (1992): "Didactic and Pedagogic Tendencies in the Norms Dictating the Translation of Children's Literature: The Case of Postwar German-Hebrew Translations", Poetics Today, 13 (1), pp. 221-230.

BONNARD, Henry (1935): Notions de style, de versification et d'histoire de la langue française, Paris, Sudel, 120 p.

EVEN-ZOHAR, Itamar (1990): "Polysystem Studies", Poetics Today, 11 (1), Tel Aviv University, The Porter Institute for Poetics and Semiotics.

LAMBERT, José (1981): "Théorie de la littérature et théorie de la traduction en France (1800-1850)", Poetics Today, 2 (4), pp. 167-170

TOURY, Gideon (1977): Translational Norms and Literary Translation into Hebrew, 1930-1945, Tel Aviv University, The Porter Institute for Poetics and Semiotics.

TOURY, Gideon (1980): In Search of a Theory of Translation, Tel Aviv University, The Porter Institute for Poetics and Semiotics.

\section{SOURCES}

DÖBLIN, Alfred (1970): Berlin Alexanderplatz, Trans. Zoya Motchane, Paris, Gallimard. DÖBLIN, Alfred (1980) [1929]: Berlin Alexanderplatz, München, DTV.

DÖBLIN, Alfred (1982): Berlin Alexanderplatz, Trans. Eugene Jolas, England, Penguin.

DÖBLIN, Alfred (c1931): Berlin Alexanderplatz, Trans. into the American by Eugene Jolas, New York, Ungar. MANN, Thomas (1965): Les Buddenbrook, Trans. Geneviève Bianquis, Paris, Fayard.

MANN, Thomas (1982): I Buddenbrooks, Trans. Ervino Pocar, Milano, Mondadori.

MANN, Thomas (1985) [1901]: Buddenbrooks, Frankfurt, Fischer.

MANN, Thomas (1985): Buddenbrooks, Trans. H.T. Lowe-Porter, England, Penguin.

MAUPASSANT, Guy de (1973) [1880]: Boule de Suif, Paris, Gallimard.

MUSIL, Robert (1962): Trois Femmes, Trans. Philippe Jaccottet, Paris, Seuil.

MUSIL, Robert (1966): Three Women, Trans. Eithne Wikins and Ernst Kaiser, New York, Dell.

MUSIL, Robert (1973): Tre Donne, Trans. Anita Rho, Torino, Einaudi.

MUSIL, Robert (1985) [1921]: Drei Frauen, Hamburg, Rowohlt.

RILKE, Rainer Maria (1957): Chant de l'amour et de la mort du cornette Christophe Rilke, Trans. Maurice Betz, Paris, Emile-Paul.

RILKE, Rainer Maria (1980) [1906]: Die Weise von Liebe und Tod des Cornets Christoph Rilke, Frankfurt, Suhrkamp.

ZWEIG, Stefan (1981): La pitié dangereuse, Trans. Alzir Hella, Paris, Grasset.

ZWEIG, Stefan (1981) [1938]: Ungeduld des Herzens, Frankfurt, Fischer.

ZWEIG, Stefan (1982): Beware of Pity, Trans. Phyllis and Trevor Blewitt, London, Jonathan Cape. 